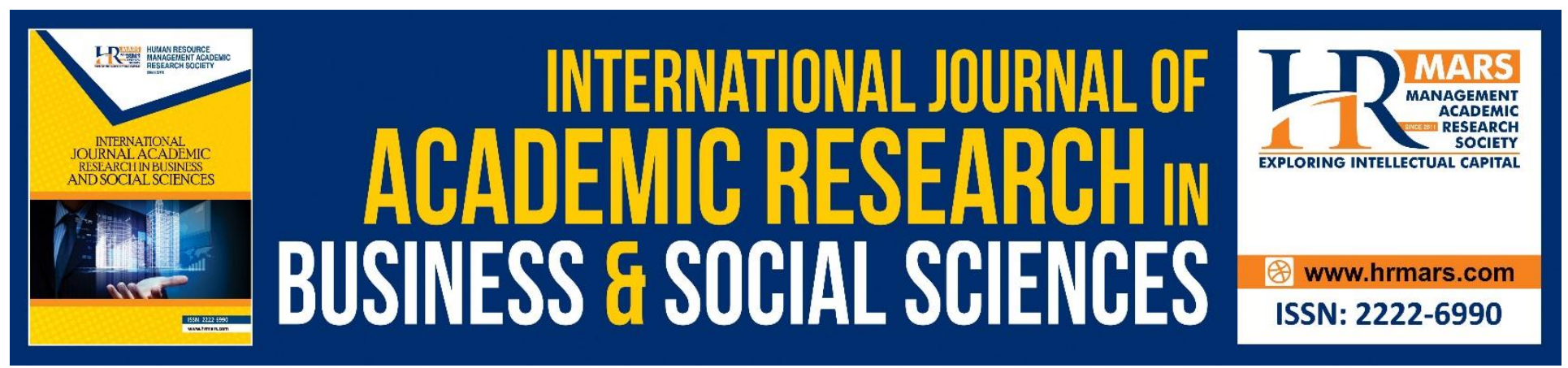

\title{
Issues and Challenges in Developing a Relationship Model between Teacher Leadership and Teacher Efficacy
}

\author{
Normah Karmani, Jamal @ Nordin Yunus
}

To Link this Article: http://dx.doi.org/10.6007/IJARBSS/v9-i2/5656

DOI: $\quad 10.6007 /$ IJARBSS/v9-i2/5656

Received: 28 Jan 2019, Revised: 22 Feb 2019, Accepted: 16 March 2019

Published Online: 18 March 2019

In-Text Citation: (Karmani \& Yunus, 2019)

To Cite this Article: Karmani, N., \& Yunus, J. @ N. (2019). Issues and Challenges in Developing a Relationship Model between Teacher Leadership and Teacher Efficacy. International Journal of Academic Research in Business and Social Sciences, 9(2), 989-993.

Copyright: (C) 2019 The Author(s)

Published by Human Resource Management Academic Research Society (www.hrmars.com)

This article is published under the Creative Commons Attribution (CC BY 4.0) license. Anyone may reproduce, distribute, translate and create derivative works of this article (for both commercial and non-commercial purposes), subject to full attribution to the original publication and authors. The full terms of this license may be seen

at: $\underline{\text { http://creativecommons.org/licences/by/4.0/legalcode }}$

Vol. 9, No. 2, 2019, Pg. 989 - 993

http://hrmars.com/index.php/pages/detail/IJARBSS

JOURNAL HOMEPAGE

Full Terms \& Conditions of access and use can be found at http://hrmars.com/index.php/pages/detail/publication-ethics 


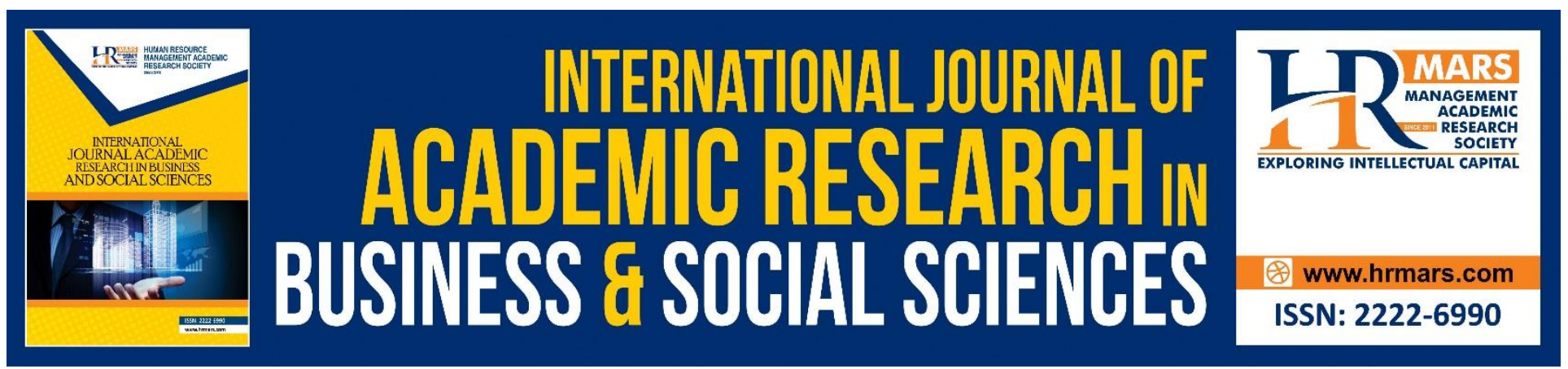

\title{
Issues and Challenges in Developing a Relationship Model between Teacher Leadership and Teacher Efficacy
}

\author{
Normah Karmani, Jamal @ Nordin Yunus \\ Faculty of Management and Economics, University Pendidikan Sultan Idris, 35900 Tanjong Malim, \\ Perak, Malaysia
}

\begin{abstract}
The purpose of this study is to develop a Model of Relationship between Teacher Leadership and Teacher Efficacy among secondary school teachers in Malaysia. The study uses both domestic and international studies. This study examines issues in the relationship between teacher leadership and teacher efficacy comprising national education policies and teacher quality. Challenges in teacher leadership and teacher efficacy include the industry revolution 4.0. international education, and international antenatal care. The implication of this study is hoped to provide additional information in the teacher leadership and teacher efficacy theory and provide a clear line of training and professionalism enhancement programs for teachers, schools and the Ministry of Education Malaysia.
\end{abstract}

Keywords: Issues, Challenges, Teachers leadership, Teacher's Efficacy

\section{Introduction}

Recognizing the fact that the country is facing the economic and globalization era of the world then, the Ministry of Education should take steps to change in today's educational policy. The dynamic Education System is necessary to ensure that the country can compete with other countries comparable. Thus, the government has taken bold steps for the first time to build the 2013-2025 Education Development Plan by gathering views of various international experts and agencies.

The Industrial Revolution 4.0 also has transformed the landscape of the world in all areas also has an impact on the development of education curriculum in Malaysia. The Malaysian Education Development Plan (PPPM) 2013-2025 has been developed to ensure that the quality of the curriculum is in line with international standards. The Industrial Revolution 4.0 is a globalization challenge that needs to be addressed through the education platform for preparing young people to face this revolution (Ministry of Education Malaysia, 2012). 
The Ministry also sees the country's need to produce high quality human capital that can compete internationally. In view of this, it is the responsibility of the ministry to build an educational policy that will produce a balanced, resilient, passionate, principled, objective and patriotic student. Students should also be provided with thinking, communication and team skills (Ministry of Education, 2012). Thus, the ministry in PPPM 2013-2025 has devised a teacher leadership model in wave 3 Action Plans: Transforming Teaching Profession into Preferred Profession. This shows the ministry's desire to create a culture of excellence based on a colleague (Ministry of Education, 2012).

\section{Issues in Teacher Leadership and Teacher Efficacy}

Teacher leadership and teacher efficacy are models built in line with the National Education Philosophy that aims to produce students who are balanced and harmonious in terms of intellect, spiritually and physically based on God's belief and obedience. The effort to produce holistic students with high thinking and high intelligence skills can take on the challenges of the 21st century of globalization.

Teachers should have high quality to produce students who can think critically of assessing the sources of information as well as being useful to the nation. This is in line with the Teacher's Education Philosophy that demands progressive and scientific-minded teachers towards the creation of united, democratic, progressive and disciplined societies.

The development of the relationship model between teacher leadership and teacher efficacy can be the basis of realizing the transformation of national education programs. The relationship model between teacher leadership and teacher efficacy can be a driving force to meet the aspirations of students contained in the National Education Blueprint 2013-2025. Teachers who have high efficacy can perform their duties and responsibilities as teachers. Therefore, these quality teachers are required to have the skills in teacher leadership to be a catalyst for students' aspirations that require students to possess knowledge, mentality, language skills, ethics and spirituality, and have a national identity (Ministry of Education, 2012).

\section{Challenges in Teacher Leadership and Teacher Efficacy}

The Malaysian education system undergoes education transformation through the Education Development Plan 2013 -2025 in line with the current globalization era. The 2013-2025 Education Development Plan in eleven shifts suggests that national education wants to be placed within the world's finest third group. Therefore, teachers need to be equipped with a variety of leadership competencies, especially the teacher leadership to improve the quality of education in Malaysia. Shift 4 in the Education Development Plan 2013-2025 also wants to place the profession of teaching as an optional profession. This is because international studies show that teacher quality is a key factor in generating holistic students in line with the Malaysian Education Blueprint (Ministry of Education Malaysia, 2012). Therefore, if the teacher lacks teacher leadership, then the quality of the teacher will be affected and ultimately the goal of the Malaysia Education Blueprint 2013-2025 to produce a balanced and highly skilled student and can compete in this era of globalization may not be attainable.

Additionally, the 4.0 industrial revolution that led to the rapid development of this technology field has led to the formation of a national curriculum so that the students can compete in 
international markets (Schwab, 2016). Along with the industrial revolution 4.0. it is found that employees with technological and innovative skills are required by 2030 . Even by 2025 , it is expected that five million jobs will shift to the automation system. This shows that future work is far different from the present. Work in the future is more to involve the creation and innovation of knowledge. The exploration, experimenting and finding interesting solutions are among the emphasized aspects (Crimson, 2018).

As such, human resources also require skills related to the automation system so that they will not be left behind in the future. The key skills in automation required by the year 2030 are manual and physical related skills, cognitive bases, high level cognitive, social and emotional, and technology. The McKinsey Model Study of the Global Institute demonstrates that there has been a large shift in activity involving basic cognitive skills to those who use higher cognitive skills. There has been an increase in high-skilled jobs. Low-skilled workers will lose and shift work that leads to inequality in employee income. Highly skilled workers will continue to be trained and enjoy higher wages (Jezard, 2018).

In addition, the Trends in International Mathematics and Science Study (TIMSS) report in 2015 shows that Malaysia has achieved excellent achievement in Science and Mathematics subjects in Grade 8. benchmarking study. Malaysia has recorded 471 points next to 24 th in the 2015 compared to 32th place with 426 points in TIMSS in 2011. Malaysia joins an international benchmarking study organized by the International Association for the Evaluation of Educational Achievement (IEA) conducted every four years aimed at making policies and planning and improving the education country. The Ministry targets the achievement of TIMSS Malaysia to rise to 500 points by 2019. Hence, the main factor for the realization of PPPM's 2013-2025 aspiration to improve the achievement of TIMSS is the improvement in the quality of teaching of teachers.

Therefore, studies on teacher leadership and teacher efficacy modelling can help educators in improving the quality of national education. Over the last decade, studies on teacher leadership models have evolved from time to time. The study of teacher leadership influencing teachers' efficacy and consequently affecting student achievement and school performance has been carried out extensively in the west (Flood \& Angelle, 2017, Frick \& Browne-Ferrigno, 2016; Greenier \& Whitehead, 2016; Sterrett \& Irizarry, 2015; Wenner \& Campbell, 2016). These teacher leadership model studies have been instrumental in practicing teacher leadership. The collaborative approach between teachers also clearly demonstrates the impact on teacher efficacy and further enhances student achievement. School organization bureaucracy structures are also identified as factors that influence relationships teacher leadership and teacher efficacy. A small part of the teacher leadership study was conducted only in the east (Chong \& Christinie Anne, 2012; Parlar \& Cansoy, 2017; Tsai, Padre, \& Pereira, 2017). In this regard, the study of teacher leadership models that have an impact on the efficacy of teachers can give a deeper understanding of the leadership of the teacher should be carried out in the context of education in the eastern country especially in Malaysia.

\section{Conclusions and Future Agenda}

The 4.0 industrial revolution that has embraced new technologies and innovations has impacted the education system especially in Malaysia. Changes need to be made in line with the needs of the education ministry to provide the young generation with the skills in accordance with current 
technological developments. Therefore, teacher leaders need to have the teacher leadership in ensuring that teachers have efficacy in carrying out their duties and responsibilities as educators to produce human capital that can compete in line with the industrial revolution 4.0. This study is expected to provide additional information in the theory of teacher leadership and teacher efficacy and to provide a clear line of training and professionalism enhancement programs for teachers, schools and the Ministry of Education Malaysia.

\section{References}

Chong, W. H., \& Christinie Anne, K. (2012). Teacher collaborative learning and teacher self-efficacy: The ase of lesson study. The Journal of Experimental Education, 3(263-283).

Crimson. (2018). Top 10 Jobs in 2030: Skills You Need Now to Land the Jobs of the Future. Retrieved from https://www.crimsoneducation.org/za/blog/jobs-of-the-future

Flood, L. D., \& Angelle, P. S. (2017). Organizational Influences of collective efficacy and trust on teacher leadership. International Studies in Educational Administration (Commonwealth Council for Educational Administration \& Management (CCEAM)), 45(3), 85-100.

Frick, W. C., \& Browne-ferrigno, T. (2016). Formation of teachers as leaders : response to the articles in this special issue. Journal of Cases in Educational Leadership, Vol. 18(1), 3-13. https://doi.org/10.1177/1942775116658822

Greenier, V. T., \& Whitehead, G. E. K. (2016). Towards a Model of Teacher Leadership in ELT: Authentic Leadership in Classroom Practice. RELC Journal, 47(1), 79-95. https://doi.org/10.1177/0033688216631203

Jezard, A. (2018). The 3 key skill sets for the workers of 2030. Retrieved from https://www.weforum.org/agenda/2018/06/the-3-skill-sets-workers-need-to-developbetween-now-and-2030/

Kementerian Pelajaran Malaysia. (2012). Pelan Pembangunan Pendidikan Malaysia 2013-2025.

Parlar, H., \& Cansoy, R. (2017). The effect of bureaucratic school structure on teacher leadership culture : A mixed study *. Educational Sciences: Theory \& Practice, (Eyfor 8), 2175-2201. https://doi.org/10.12738/estp.2017.6.0150

Schwab, K. (2016). The fourth industrial revolution. Switzerland: World Economic Forum.

Sterrett, W., \& Irizarry, E. (2015). Beyond " autopsy data ": Bolstering teacher leadership , morale , and school improvement. Journal of Cases in Educational Leadership, Vol. 18(1), 3-13. https://doi.org/10.1177/1555458914551828

Tsai, K. C., Padre, A., \& Pereira, T. (2017). DEVELOPMENT OF THE TEACHER LEADERSHIP STYLE SCALE, 45(3), 477-490.

Wenner, J. A., \& Campbell, T. (2016). The theoretical and empirical basis of teacher leadership : A review of the literature. Review of Educational Research, $X X(X), 1-38$. https://doi.org/10.3102/0034654316653478 